\title{
Kemampuan Kolonisasi Cendawan Endofit dan Peningkatan Pertumbuhan Bibit Cabai
}

\author{
Endophytic Fungus Colonization Ability and Enhanced Growth of Chili Seeds
}

\author{
Evan Purnama Ramdan ${ }^{1}$, Efi Toding Tondok ${ }^{2}$, Suryo Wiyono ${ }^{3}$, Sri Hendrastuti Hidayat ${ }^{4}$, Widodo \\ ${ }^{1}$ Program Studi Agroteknologi Fakultas Teknologi Industri, Universitas Gunadarma Depok \\ 2,3,4,5 Departemen Proteksi Tanaman Fakultas Pertanian, IPB University Bogor
}

\section{ARTICLE INFO}

Article history:

DOI:

$\underline{10.30595 / \text { pspfs.v2i. } 175}$

Submitted:

July 29, 2021

Accepted:

Sept 10, 2021

Published:

Nov 10, 2021

Keywords:

Capsicum Annum, Fungus

Isolation, Plant Growth

Enhancement

\begin{abstract}
Endophytic fungi are fungi that live in healthy plant tissues without causing disease symptoms. Endophytic fungi in chili have been tested as both biocontrol agents and growth promoters, but their colonization has not been reported. Therefore, this study aimed to determine the level of colonization of endophytic fungi and its effect on the growth of chili seedlings. A total of 8 endophytic fungi were prepared at a density of $2.8 \times$ $106 \mathrm{CFU} \mathrm{mL}-1$. Then the endophytic fungus was inoculated 2 times, first by soaking the seeds, and secondly by watering the endophytic fungus suspension on chili seedlings aged 3 weeks after sowing. Endophytic fungi were re-isolated on chili seedlings that were 4 weeks old after sowing on the roots and stems to determine their colonization ability. Chili seeds were then maintained for up to 4 weeks after transplanting to observe their growth. The results showed that the endophytic fungal colonization ranged from $26-60 \%$ on the chili root, while at the base of the stem it was $20-40 \%$ with a different pattern of colonization distribution. In addition, endophytic fungus colonization was also able to increase the shoot height and root length of chili seedlings.
\end{abstract}

This work is licensed under a Creative Commons Attribution 4.0 International License.

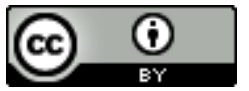

Corresponding Author:

Evan Purnama Ramdan

Program Studi Agroteknologi Fakultas Teknologi Industri

Universitas Gunadarma Depok

Email : evan_ramdan@staff.gunadarma.ac.id

\section{PENDAHULUAN}

Cendawan endoit didefinisikan Schulz dan Boyle (2006) sebagai cendawan yang memiliki kemampuan untuk hidup dalam jaringan tanaman tanpa menyebabkan adanya gejala penyakit. Cendawan endofit pada cabai telah berhasil diisolasi Ramdan dkk. (2013) menunjukkan adanya kelimpahan yang berbeda pada bagian akar, batang, dan cabang tanaman cabai. Berdasarkan kelimpahan tersebut, bagian akar merupakan yang paling banyak ditemukan cendawan endofit dibandingkan bagian yang lain. Cendawan endofit yang berasosiasi dengan tanaman cabai telah dilaporkan mampu meningkatkan viabilitas benih dengan ditunjukkan oleh peningkatan tinggi tajuk dan panjang akar kecambah cabai (Ramdan dkk. 2013; Irawat dkk. 2017). Pada tanaman cabai dewasa pun, cendawan endofit telah dilaporkan mampu meningkatkan pertumbuhan dan produksi cabai (Marnita et al., 2017). Cendawan endofit asal tanaman cabai telah dilaporkan sebagai agens hayati untuk P.capsici secara in vitro, P. capsici secara in vivo, F. oxsporum, antraknosa, dan layu bakteri (Paul et al., 2012; Asniah dkk., Istikorini, 2008; Irawati dkk., 2016; Ramdan dkk., 2017). 
Berdasarkan peran cendawan endofit sebagai agens hayati maupun pemacu pertumbuhan tanaman, penting untuk mengetahui kemampuan dalam mengkolonisasi inangnya. Pengujian kemampuan kolonisasi ini akan menjadi pembuktian bahwa cendawan endofit berhasil masuk ke dalam jaringan tanaman. Oleh karena itu, pada penelitian ini akan menguji kemampuan kolonisasi dari 8 isolat cendawan endofit pada bibit cabai. Selain itu, akan diamati pula pengaruhnya terhadap parameter pertumbuhan bibit cabai.

\section{METODE PENELITIAN}

\section{Bahan}

Bahan yang digunakan pada penelitian ini adalah 8 isolat cendawan endofit (Fusarium galur MAGR1, Penicillium galur PAB2, Penicillium galur MAG1, Aspergillus galur HAG1, Hifa steril HAJ1, Hifa steril HAJ2, Hifa steril PBG7, dan isolat CBG5), dan benih cabai varietas gelora.

\section{Alat}

Sementara itu alat yang digunakan yaitu IKA T18 Basic Ultra Turrax homogenizer untuk menghancurkan kumpulan miselium dari cendawan endofit hifa steril.

Prosedur Penelitian

Inokulum cendawan endofit dibuat dengan dua metode berbeda. Pertaman, pemanenan konidia dari cendawan endofit yang membentuk konidia dengan cara menambahkan akuades steril $10 \mathrm{~mL}$ pada biakan cendawan endofit. Kemudian konidia dipanen dengan cara menggosok permukaan koloni untuk memisahkan konidia dari media agar menggunakan jarum ose. Kedua, penghancuran kumpulan miselium dari cendawan endofit yang memiliki hifa steril dengan cara menumbuhkan cendawan endofit pada media PDB yang selanjutnya di shaker selama 7 hari pada kecepatan $130 \mathrm{rpm}$. Setelah itu, kumpulan miselium dipisahkan dari PDB, dibilas sebanyak tiga kali menggunakan aquades steril. Selanjutnya kumpulan miselium di masukkan ke dalam aquades steril $100 \mathrm{~mL}$ dan dihancurkan menggunakan IKA ULTRA-TURAX T18 Basic pada kecepatan $3.500-24.000 \mathrm{rpm}$ selama 5 menit atau hingga didapatkan suspensi relatif homogen. Masing-masing inokulum cendawan endofit yang diinokulasikan memiliki kerapatan $2.8 \times 106$ CFU mL-1.

Tahapan selanjutanya yaitu benih yang sudah melalui proses sterilisasi permukaan disemai pada baki semai yang mempunyai 50 lubang. Sebelum disemai benih terlebih dahulu diinokulasi supsensi cendawan endofit selama 12 jam. Selanjutnya cendawan endofit diinokulasikan kembali setelah bibit cabai berumur 3 minggu setelah semai. Pindah tanam dilakuan setelah bibit cabai berumur 4 minggu setelah semai ke polybag yang berisi media tanah dan pupuk kandang (1:1). Pada umur 4 minggu setelah semai bibit cabai diambil sebanyak 5 tanaman dari setiap perlakuan untuk diujji kemampuan kolonisasi cendawan endofit. Pengujian dilakukan dengan metode reisolasi cendawan endofit yang telah dinokulasikan. Reisolasi dilakukan pada bagian akar meliputi akar primer, akar lateral, rambut akar, dan ujung akar. Sementara itu reisolasi pada bagian batang diambil dari bagian pangkal batang $(5 \mathrm{~cm}$ dari permukaan tanah). Pengamatan pertumbuhan diamati selama 4 minggu setelah pindah tanam meliputi tinggi tanaman dan jumlah daun, sedangkan panjang akar diamati pada akhir pengamatan.

Pengujian kolonisasi cendawan endofit menggunakan rancangan acak lengkap (RAL) dengan 5 kali ulangan. Sementara pengujian terhadap pertumbuhan bibit cabai menggunakan rancangan acak kelompok (RAK) dengan 3 kali ulangan. Masing-masing data yang diperoleh kemudian dianalisis menggunakan program SAS versi 9.1. Perlakuan yang menunjukkan beda nyata kemudian diuji lanjut menggunakan uji Tukey pada taraf $5 \%$.

\section{HASIL DAN PEMBAHASAN}

Berdasarkan pengamatan kolonisasi, cendawan endofit mampu mengkoloni bagian akar dan pangkal batang bibit cabai berturut-turut antara 26-60\% dan 20-40\% (Gambar 1). 


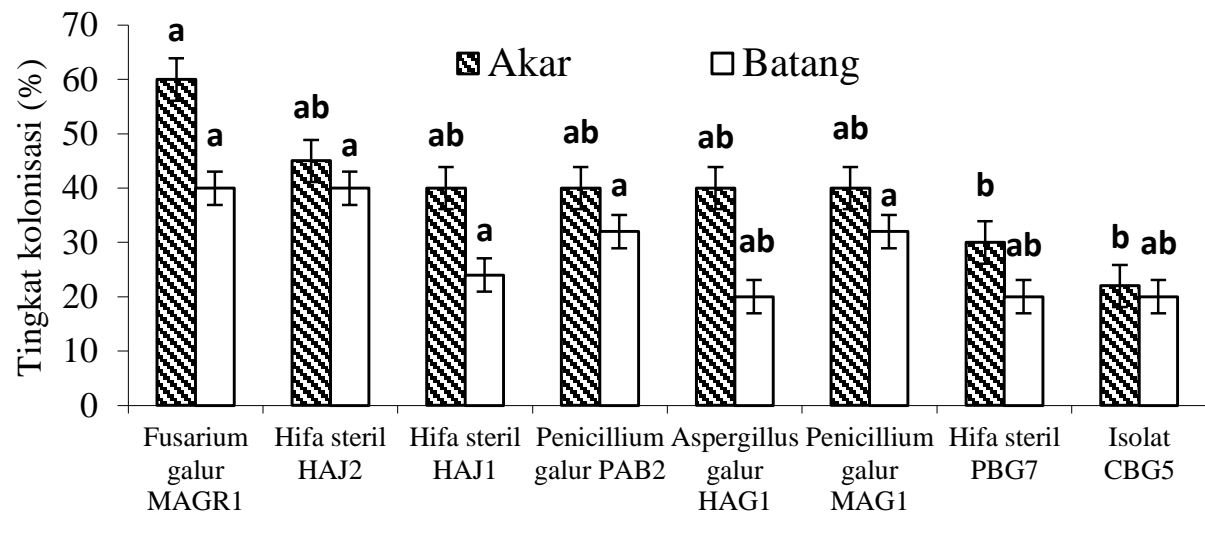

Cendawan endofit

Gambar 1. Tingkat kolonisasi cendawan endofit pada bibit cabai

Setiap cendawan endofit yang diaplikasikan, tingkat kolonisasinya lebih tinggi pada akar dibandingkan dengan pangkal batang. Hal ini dipengaruhi oleh metode inokulasi disekitar perakaran, yang menyebabkan cendawan endofit menginokulasi bagian akar terlebih dahulu baru kemudian mengkoloni pangkal batang. Sesuai dengan penelitian sebelumnya bahwa cendawan endofit mampu mengkoloni ruang antar sel maupun pada jaringan korteks akar cabai, kubis, dan bawang merah (Seviani dkk., 2016; Hapipah dkk., 2018; Fitriani dkk., 2019), serta batang tanaman cabai (Trizelia dkk., 2020).

Sebaran kolonisasi pada jaringan pangkal batang secara vertikal sampai $5 \mathrm{~cm}$ di atas permukaan tanah menunjukkan pola yang berbeda (Gambar 2). Semua cendawan endofit mampu mengkoloni cm-1 pada pangkal batang dengan tingkat kolonisasi 100\%. Penicillium galur PAB 2 dan isolat CBG 5 mampu mengkoloni (100\%) sampai cm-2. Sementara hifa steril HAJ1, hifa steril HAJ 2, dan Penicillium galur MAG1 mampu mengkoloni pangkal batang sampai cm-3. Hal ini menunjukkan bahwa cendawan endofit berhasil establish dan berkembang di dalam jaringan tanaman, tidak hanya di akar tetapi juga sistemik sampai bagian pangkal batang (Ramdan dkk., 2017).

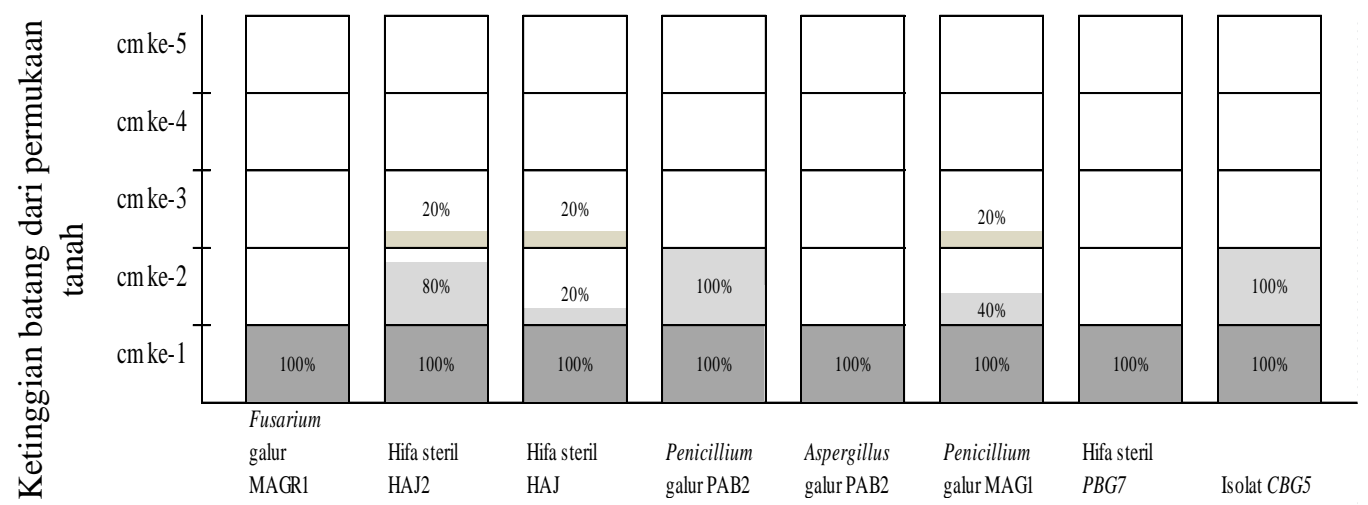

Cendawan endofit

Gambar 2. Pola sebaran cendawan endofit pada pangkal batang bibit cabai

Respon tinggi tajuk bibit cabai terhadap perlakuan cendawan endofit menunjukkan hasil yang berbeda (Gambar 3). Berdasarkan uji statistik, hifa steril HAJ2, hifa steril HAJ1, Penicillium galur MAG1, hifa steril PBG7, dan isolat CBG5 menunjukkan adanya pengaruh nyata terhadap tinggi tajuk dibandingkan kontrol dan perlakuan lainnya. Sementara pada pengamatan jumlah daun, semua cendawan endofit tidak berpengaruh nyata dibandingkan kontrol (Gambar 4). Meskipun demikian, semua cendawan endofit memberikan pengaruh nyata terhadap respon panjang akar dibandingkan dengan kontrol (Gambar 5). Hasil tersebut sesuai dengan kemampuan cendawan endofit $100 \%$ mengkoloni akar bibit cabai. 


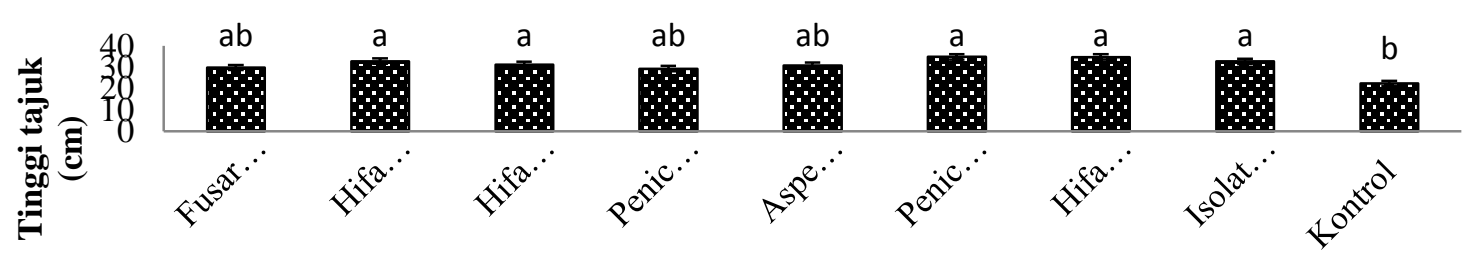

Cendawan endofit

Gambar 3. Respon tinggi tajuk bibit cabai terhadap inokulasi cendawan endofit

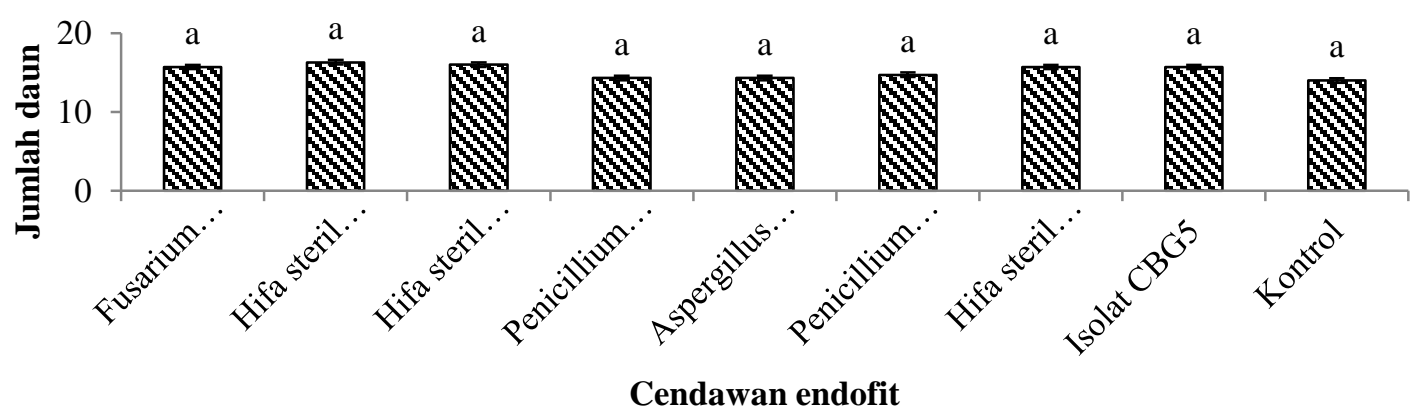

Gambar 4. Respon jumlah daun terhadap inokulasi cendawan endofit

Peran cendawan endofit terhadap pertumbuhan tanaman dapat berupa peningkatkan ketersediaan nutrisi, produksi senyawa pengatur tumbuh seperti giberelin, akusin, dan sitokinin, maupun penekanan mikroba pengganggu tanaman (Gao et al., 2010; Hamayun et al., 2010; Khan et al., 2012; Waqas et al., 2012; de Lima Favaro et al., 2012; Manici et al., 2014; Groszmann et al., 2015). Respon pertumbuhan yang baik pada bibit cabai juga diduga dengan adanya peningkatan panjang akar. Akar yang panjang dan jumlah akar lateral dan rambut akar yang meningkat menjadikan daya jangkau akar menyerap nutrisi menjadi lebih dalam sehingga penyerapan nutrisi maksimal.

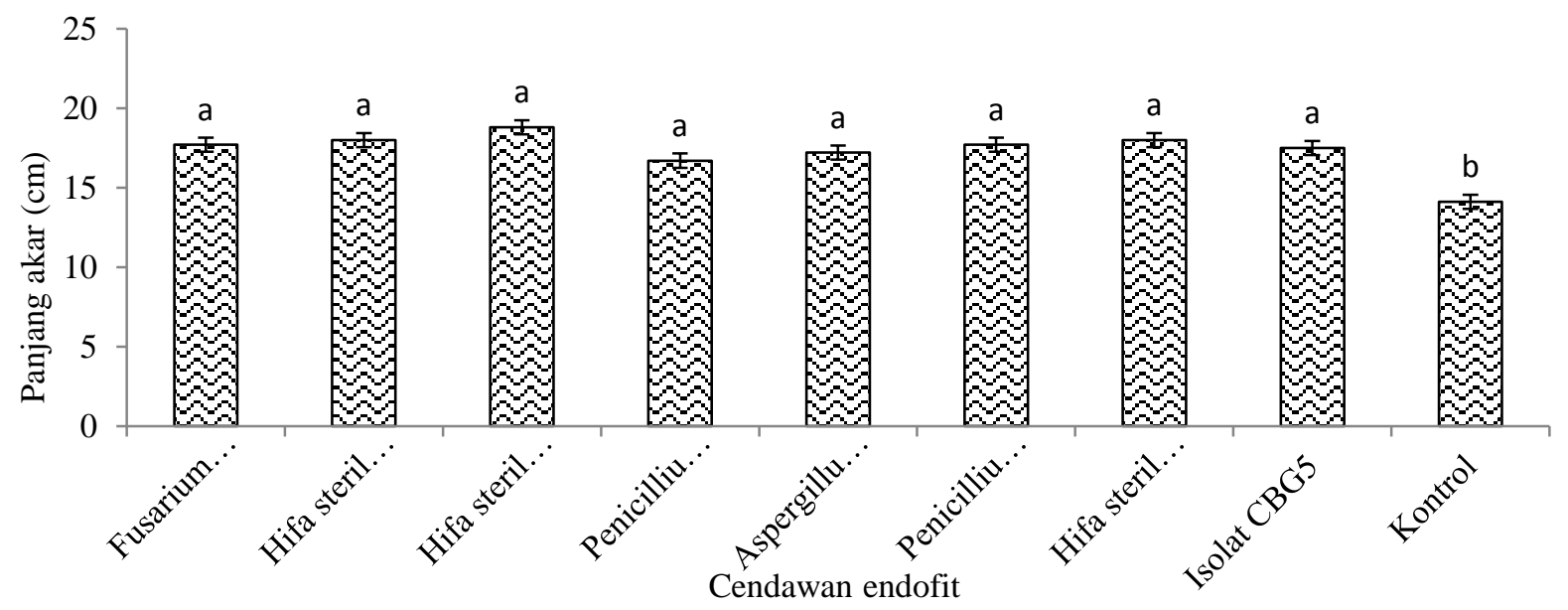

Gambar 5. Respon panjang akar terhadap inokulasi cendawan endofit

\section{KESIMPULAN}

Berdasarkan temuan pada hasil penelitian, dapat disimpulkan bahwa:

1. Cendawan endofit mampu mengkolonisasi akar dan batang bibit cabai dengan tingkat kolonsasi berturutturut 26-60\% dan 20-40\% dengan isolat Fusarium galur MAGR1 sebagai cendawan terbaik mengkoloni akar dan batang.

2. Cendawan endofit mempunyai pola sebaran kolonisasi yang berbeda pada batang cabai dari cm pertama sampai $\mathrm{cm}$ ketiga dari pangkal batang. Cendawan yang mampu sistemik sampai $\mathrm{cm}$ ketiga yaitu Hifa steril HAJ2, hifa steril HAJ1, dan Penicillium galur MAG1. 
3. Cendawan endofit mampu meningkatkan pertumbuhan bibit cabai dengan peningkatan tinggi tajuk dan panjang akar dibandingkan dengan kontrol.

\section{DAFTAR PUSTAKA}

de Lima Favaro, L.C., de Souza Sebastianes, F.L., \& Arau' jo, W.L. (2012). Epicoccum nigrum P16, a sugarcane endophyte, produces antifungal compounds and induces root growth. PLoS ONE, 7: 1-10.

Fitriani, M.L., Wiyono, S., \& Sinaga, M.S. (2019). Potensi kolonisasi mikoriza arbuskular dan cendawan endofit dan kemampuannya dalam pengendalian layu Fusarium pada bawang merah. Jurnal Fitopatologi Indonesia, 15(6):228-238.

Gao, F.K., Dai, C.C., \& Liu, X.Z. (2010). Mechanism of fungal endophytes in plant protection against pathogens. African J. of Microbiol. Research, 4(13): 1351-46.

Groszmann, M., Gonzalez-Bayon, R., Lyons, R.L., Greaves, I.K., Kazan, K., Peacock, W.J., \& Dennis, E.S. (2015). Hormone-regulated Defense and Stress Response Networks Contribute to Heterosis in Arabidopsis F1 Hybrids.In: Proceedings of the National Academy of Sciences. Washington DC, National Academy of Sciences, 112 (46):.E6397-E6406.

Hafifah, R., Rahayu, G., \& Hidayat, I. (2018). Uji simbiosis kapang endofit pada tanaman Chinese cabbage (Brassica rapa) dan cabai (Capsicum annuum). Jurnal Mikologi Indonesia, 2(1): 7-15.

Hamayun, M., Khan, S.A., Khan, A.L., Tang, D.S., Hussain, J., Ahmad, B., Anwar, Y., \& Lee, I.J. (2010). Growth promotion of Cucumber by pure cultures of gibberellins-producting. Phoma sp. GAH7. J Micribiol Biotechnol. 26:889-894.

Irawati, A.F.C., Sastro, Y., Sulastri, Suhartono, M.T., Mutaqin, K.H., \& Widodo. (2016). Cendawan endofit yang potensial meningkatkan ketahanan cabai merah terhadap penyakit layu bakteri. J Fitopatol Indones., 12(4):133-141.

Irawati, A.F.C., Mutaqin, K.H., Suhartono, M.T, Sasro, Y., Sulastri, \& Widodo. (2017). Eksplorasi dan pengaruh cendawan endofit yang berasal dari akar tanaman cabai terhadap pertumbuhan benih cabai merah. Jurnal Hortikultura, 27(1):105-112.

Istikorini Y. (2008). Potensi cendawan endofit untuk mengendalikan penyakit antraknosa pada cabai (Capsicum annum L.) [disertasi]. Bogor (ID): Institut Pertanian Bogor.

Khan, S.A., Hamayun, M., Khan, A.L., Lee, I.J., Shinwari, Z.K., \& Kim, J. (2012). Isolation of plant growth promotic fungi from dicots inhabiting coastal sand dunes of Korea. J Bot., 44(4):1453-1460.

Manici, L.M., Kelderer, M., Caputo., F., \& Mazzola, M. (2014). Auxin-mediated relationships between apple plants and root inhabiting fungi: Impact on root pathogens and potentialities of growth-promoting populations', Plant Pathol., 64(4): 851-43.

Paul, N.C., Deng, J.X., Sang, H.K., Choi, Y.P., \& Yu, S.H.. (2012). Distribution and antifungal activity of endophytic fungi in different growth stages of chili pepper (Capsicum annuum L.) in Korea. Plant Pathol J. 28:10-19.

Ramdan, E.P., Widodo, Tondok, E.T., Wiyono, S., \& Hidayat, S.H. (2013). Cendawan endofit nonpatogen asal tanaman cabai dan potensinya sebagai agens pemacu pertumbuhan tanaman. Jurnal Fitopatologi Indonesia, 9(5): 139-144.

Ramdan, E.P., Tondok, E.T., Wiyono, S., Hidayat, S.H., \& Widodo. (2017). Potensi cendawan endofit sebagai pengendali hayati penyakit busuk pangkal batang (Phytophthora capisci) pada bibit cabai. Jurnal Fitopatologi Indonesia, 13(5): 161-167.

Schulz, B. \& Boyle, C. (2006). What are endophytes?, Soil Biology: Microbial Root Endophytes, 9: 13-1.

Seviani, D.N., Rahayu, G., \& Hidayat, I. (2016). Potensi simbiosis cendawan endofit pada beberapa tanaman pangan dan hortikultura. Jurnal Mikologi Indonesia, 1(1): 1-10.

Trizelia, Sulyanti, E., \& Saputra, R. (2020). Kemampuan kolonisasi cendawan endofit Trichoderma sp. dan Beauvaria bassiana pada tanaman cabai dan pengaruhnya terhadap populasi kutu daun Myzzus persicae. Dalam Prosiding Seminar Nasional Fakultas Pertanian UPN "Veteran" Yogyakarta 2020. Yogyakarta, Indonesia. 
Waqas, M., Khan, A.L., Kamran M., Hamayun, M., Kang, S.M.,.Kim, Y.H., \& In-Jung Lee I.J. (2012). Endophytic fungi produce gibberellins and indoleacetic acid and promotes host-plant growth during stress. Molecules, 17: 10773-54. 